\title{
Methodology for the spatialisation of a reference evapotranspiration from SRTM data ${ }^{1}$
}

\author{
Metodologia para espacialização da evapotranspiração de referência a partir de dados \\ SRTM
}

\author{
Joaquim Branco de Oliveira ${ }^{2 *}$, Francisco Dirceu Duarte Arraes $^{3}$ e Paula Carneiro Viana ${ }^{4}$
}

\begin{abstract}
The aim of this work was to develop a methodology for the spatialisation of mean monthly reference evapotranspiration for the State of Ceará, using the Hargreaves and Samani equation, from estimated air-temperature data based on digital elevation models. The study area is located in northeastern Brazil, between the latitudes $2.5^{\circ}$ and $8^{\circ}$ South and longitudes $37^{\circ}$ and $42^{\circ}$ West. The data used in the study are from the network of meteorological stations of the National Institute of Meteorology. The equation proposed by Hargreaves and Samani was used to estimate ET, being spatialised in the form of maps using the Idrisi Andes $\odot$ software for the manipulation of digital data of latitude, longitude and altitude in order to obtain the variables of the equation. The study used the SRTM data as an altitude map. To compare the results obtained by the Hargreaves and Samani equation to temperatures maps calculated from the digital terrain model, the value of ET was determined for each location from weather data with the help of the REF-ET program. The coefficients of determination of the temperature models generated varied between 0.88 and 0.98 , which showed a good correlation between the air temperature and the geographic data. The proposed methodology for the spatialisation of ET from temperature maps obtained by SRTM, proved to be a viable alternative, given the results of statistical analysis when compared to the standard method.
\end{abstract}

Key words: Digital elevation model. Hargreaves and Samani. Air temperature. GIS.

RESUMO - O objetivo do presente trabalho foi desenvolver uma metodologia para espacialização da evapotranspiração de referência média mensal pela equação de Hargreaves e Samani para o Estado do Ceará, a partir de dados de temperatura do ar estimados em função de modelos digitais de elevação. A área do estudo se encontra localizada na região Nordeste do Brasil, entre os paralelos $2,5^{\circ}$ e $8^{\circ}$ de latitude Sul e os meridianos $37^{\circ}$ e $42^{\circ}$ de longitude Oeste. Os dados utilizados no estudo são oriundos da rede de estações meteorológicas pertencentes ao Instituto Nacional de Meteorologia. A equação proposta por Hargreaves e Samani foi utilizada para a estimativa da $\mathrm{ET}_{\mathrm{o}}$ sendo espacializada na forma de mapas através do software Idrisi Andes $($ ) pela manipulação dos dados digitais de latitude, longitude e altitude para obtenção das variáveis da equação. Foram utilizados os dados do SRTM, como mapa de altitude. Para a comparação dos resultados obtidos pela equação de Hargreaves e Samani pelos mapas de temperaturas calculadas a partir do modelo numérico do terreno, foi determinado o valor de $\mathrm{ET}_{\mathrm{o}}$ para cada localidade a partir dos dados climáticos com auxílio do programa REF-ET. Os coeficientes de determinação dos modelos de temperatura gerados variaram entre 0,88 a 0,98 , o que demonstrou boa correlação entre a temperatura do ar e os dados geográficos. A metodologia proposta para espacialização de $\mathrm{ET}_{\mathrm{o}}$ a partir de mapas de temperaturas obtidos pelo SRTM, mostrou-se uma alternativa viável tendo em vista os resultados da análise estatística em comparação ao método padrão.

Palavras-chave: Modelo digital elevação. Hargreaves e Samani. Temperatura do ar. SIG.

\footnotetext{
*Autor para correspondência.

${ }^{1}$ Recebido para publicação em 20/03/2012; aprovado em 16/10/2012

Parte da Monografia do terceiro autor apresentada ao Instituto Federal de Educação, Ciência e Tecnologia do Ceará/IFCE - Campus Iguatu

${ }^{2}$ Instituto Federal de Educação, Ciência e Tecnologia do Ceará, Iguatu-CE, Brasil, joaquimbrancodeoliveira@gmail.com

${ }^{3}$ Programa de Pós-Graduação em Engenharia de Sistemas Agrícolas, Departamento de Engenharia de Biossistemas ESALQ/USP-SP, Brasil, dirceuarraes@gmail.com

${ }^{4}$ Programa de Pós-Graduação em Solo e Água, Universidade Federal Rural do Semiárido/UFERSA, Mossoró-RN, Brasil, paulinhatmgm @ hotmail.com
} 


\section{INTRODUCTION}

The reference evapotranspiration $\left(\mathrm{ET}_{\mathrm{o}}\right.$ ) is a nonlinear complex, which depends on various climatic elements, and refers to that water removed from an area of land completely covered with a reference crop, and which is healthy, not under any kind of stress and has an ample supply of water (ALLEN et al. 1998; WALTER et al., 2000). The estimation of $\mathrm{ET}_{\mathrm{o}}$ is needed to give support to irrigation sizing and management, in hydrological studies of watersheds, in models for estimating crop yield, and in other models to simulate land water balance.

There are a multitude of methods for estimating ET. Techniques for estimation are based on one or more atmospheric variables such as air temperature, solar radiation, net radiation, air humidity, wind speed or any measurement related to these variables, such as evaporation. However, only some of these models are accurate and reliable, others giving only a rough approximation. Most of them were developed for use in specific studies, and are more suitable for use in climates similar to that for which they were developed.

Many studies have confirmed the superiority of the Penman-Monteith equation (ALLEN, 1986; GAVILÁN; BERENGENA; ALLEN, 2007; LOPEZURREA et al., 2006; PEREIRA; PRUITT, 2004; VENTURA et al., 1999). This method has two advantages over many other equations: first, because of its physical basis it can be used globally without any calibrations due to location, second, it is a welldocumented equation and has been tested using a variety of lysimeters under various climatic conditions (DROOGERS; ALLEN, 2002).

Recently a version of the Penman-Monteith equation, parameterized by the FAO in its manual 56, was established as a standard for the calculation of reference evapotranspiration (ALLEN et al., 1998). The calculation procedure requires accurate measurements of air temperature and relative humidity, solar radiation and wind speed. Unfortunately there is a limited number of meteorological stations where these climatic variables are measured with precision and satisfactory geographic distribution, even in developed countries (GAVILAN et al., 2006; XU et al., 2006).

The lack of meteorological data was solved by Hargreaves and Samani (1985) who developed a simple method to estimate $\mathrm{ET}_{0}$. The Hargreaves and Samani equation (1985) is based on the average air temperature, and the maximum and minimum air temperatures, usually available in most weather stations around the world, and on extraterrestrial solar radiation (DROOGERS; 2002; HARGREAVES; 1985).
The application of hydrological models requires the spatial and temporal quantification of the variables of the hydrological system, among them ET (XU et al., 2006). Several studies have used the GIS (Geographic Information System) to specify weatherdata(BARBOSA, TEIXEIRA; GONDIM, 2005; BARDIN; PEDRO JÚNIOR; MORAES, 2010; CARGNELUTTI FILHO; MALUF; MATZENAUER, 2008; PEZZOPANE et al., 2004; ROCHA et al., 2011). Therefore the aim of this work was to develop a methodology for the spatialisation of the average monthly reference evapotranspiration by the Hargreaves and Samani equation (1985) for the state of Ceará, using air-temperature data estimated according to digital models of elevation, and compare values obtained from the traditional method based on data from meteorological stations.

\section{MATERIAL E METHODS}

The study was carried out in the state of Ceará, which is located in northeastern Brazil, between the latitudes $2.5^{\circ}$ and $8^{\circ}$ South, and longitudes $37^{\circ}$ and $42^{\circ}$ West. According to the Köppen climate classification the study area has three types of climate: BSw'h', Aw' and $\mathrm{Cw}$, with the predominance in approximately $80 \%$ of the area of BSw'h' (hot semiarid). The data used in the study are from the network of meteorological stations in the state (Table 1 and Figure 1), belonging to the National Institute of Meteorology (INMET). The stations from the surrounding states were used to provide boundary conditions.

To estimate the reference evapotranspiration the model proposed by Hargreaves and Samani (1985) was used:

$E T_{o}=0,0023(T x-T n)^{0,5}(T m+17,8) R a$

where: $\mathrm{ET}_{\mathrm{o}}\left(\mathrm{mm} \mathrm{day}^{-1}\right)$ is the reference evapotranspiration; $\mathrm{Tx}, \mathrm{Tn}$ and $\mathrm{Tm}$ represent the maximum, minimum and average air temperatures respectively $\left({ }^{\circ} \mathrm{C}\right)$; and $\mathrm{Ra}$, the solar radiation at the top of the atmosphere $\left(\mathrm{mm} \mathrm{day}^{-1}\right)$.

For estimates of the spatialised maximum, minimum and average temperatures a multiple linear regression model was tested, with altitude, latitude and longitude as independent variables and the measured temperature as the dependent variable, based on the general quadratic model:

$$
\begin{aligned}
& T_{i}=A_{0}+A_{1} \cdot h+A_{2} \cdot h^{2}+A_{3} \cdot \lambda+A_{4} \cdot \lambda^{2}+A_{5} \cdot \varphi \\
& +A_{6} \varphi^{2}+A_{7} \cdot h \cdot \varphi+A_{g} \cdot h \cdot \lambda+A_{9} \cdot \varphi \cdot \lambda
\end{aligned}
$$

where: $\mathrm{Ti}$ is the mean monthly temperature $(\mathrm{i}=1,2,3$ $\ldots, 12) ; \lambda$ is the longitude in degrees; $\varphi$ is the latitude 
Table 1 - Location of the weather stations

\begin{tabular}{|c|c|c|c|c|}
\hline Location & State & Latitude & Longitude & Altitude \\
\hline Sobral (Sbr) & $\mathrm{CE}$ & $-3^{\circ} 41^{\prime} 10^{\prime \prime}$ & $-40^{\circ} 20^{\prime} 59^{\prime \prime}$ & 69,4 \\
\hline Fortaleza (Frt) & $\mathrm{CE}$ & $-3^{\circ} 43^{\prime} 02^{\prime \prime}$ & $-38^{\circ} 32^{\prime} 35^{\prime \prime}$ & 21,1 \\
\hline Guaramiranga (Grm) & $\mathrm{CE}$ & $-4^{\circ} 15^{\prime} 48^{\prime \prime}$ & $-38^{\circ} 55^{\prime} 59^{\prime \prime}$ & 900,0 \\
\hline Jaguaruana (Jgr) & $\mathrm{CE}$ & $-4^{\circ} 52^{\prime} 02^{\prime \prime}$ & $-37^{\circ} 46^{\prime} 52^{\prime \prime}$ & 12,2 \\
\hline Crateús (Crt) & $\mathrm{CE}$ & $-5^{\circ} 10^{\prime} 42^{\prime}$ & $-40^{\circ} 40^{\prime} 39^{\prime \prime}$ & 274,7 \\
\hline Quixeramobim (Qxr) & $\mathrm{CE}$ & $-5^{\circ} 11^{\prime} 57^{\prime \prime}$ & $-39^{\circ} 17^{\prime} 34^{\prime \prime}$ & 191,7 \\
\hline Morada Nova (MN) & $\mathrm{CE}$ & $-5^{\circ} 06^{\prime} 24^{\prime \prime}$ & $-38^{\circ} 22^{\prime} 21^{\prime \prime}$ & 52,1 \\
\hline Apodi (Apd) & RN & $-5^{\circ} 39^{\prime} 51^{\prime \prime}$ & $-37^{\circ} 47^{\prime} 56^{\prime \prime}$ & 67,9 \\
\hline Mossoró (Msr) & RN & $-5^{\circ} 11^{\prime} 15^{\prime \prime}$ & $-37^{\circ} 20^{\prime} 39^{\prime \prime}$ & 16,9 \\
\hline Tauá (Tau) & $\mathrm{CE}$ & $-6^{\circ} 00^{\prime} 11^{\prime \prime}$ & $-40^{\circ} 17^{\prime} 34^{\prime \prime}$ & 402,6 \\
\hline Iguatu (Igt) & $\mathrm{CE}$ & $-6^{\circ} 21^{\prime} 34^{\prime \prime}$ & $-39^{\circ} 17^{\prime} 55^{\prime \prime}$ & 217,2 \\
\hline São Gonçalo (SG) & $\mathrm{PB}$ & $-6^{\circ} 27^{\prime} 00^{\prime \prime}$ & $-38^{\circ} 07^{\prime} 48^{\prime \prime}$ & 233,1 \\
\hline Florania (Flr) & RN & $-6^{\circ} 07^{\prime} 38^{\prime \prime}$ & $-36^{\circ} 49^{\prime} 06^{\prime \prime}$ & 315,7 \\
\hline Campos Sales (CS) & $\mathrm{CE}$ & $-7^{\circ} 04^{\prime} 28^{\prime \prime}$ & $-40^{\circ} 22^{\prime} 34^{\prime \prime}$ & 566,3 \\
\hline Picos (Pcs) & PI & $-7^{\circ} 04^{\prime} 37^{\prime \prime}$ & $-41^{\circ} 28^{\prime} 01^{\prime \prime}$ & 206,4 \\
\hline Barbalha (Bar) & $\mathrm{CE}$ & $-7^{\circ} 18^{\prime} 40^{\prime \prime}$ & $-39^{\circ} 18^{\prime} 15^{\prime \prime}$ & 415,0 \\
\hline Triunfo (Trf) & $\mathrm{PE}$ & $-7^{\circ} 50^{\prime} 17^{\prime \prime}$ & $-38^{\circ} 06^{\prime} 06^{\prime \prime}$ & 1004,4 \\
\hline Monteiro (Mtr) & PB & $-7^{\circ} 53^{\prime} 22^{\prime \prime}$ & $-37^{\circ} 07^{\prime} 12^{\prime \prime}$ & 599,2 \\
\hline Parnaíba (Par) & PI & $-3^{\circ} 04^{\prime} 48^{\prime \prime}$ & $-41^{\circ} 46^{\prime} 12^{\prime \prime}$ & 79,5 \\
\hline Paulistana (Plt) & PI & $-8^{\circ} 08^{\prime} 08^{\prime \prime}$ & $-41^{\circ} 08^{\prime} 59^{\prime}$ & 359,6 \\
\hline Piripiri (Pri) & PI & $-4^{\circ} 16^{\prime} 12^{\prime \prime}$ & $-41^{\circ} 46^{\prime} 48^{\prime \prime}$ & 161,12 \\
\hline
\end{tabular}

Figure 1 - Spatial distribution of the weather stations

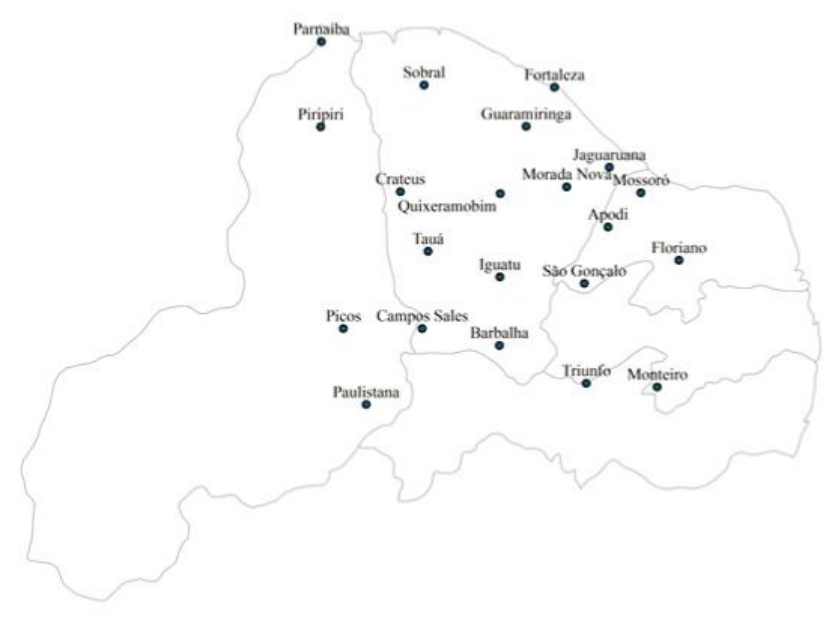

in degrees; $h$ is the altitude in meters; and $A_{n}$ are the regression coefficients.

The generated equations were evaluated by the coefficient of determination $\left(\mathrm{R}^{2}\right)$ and $\mathrm{F}$ - test at a $5 \%$ level of significance.
The regression coefficients obtained from the temperature models were applied to specify $\mathrm{ET}_{\mathrm{o}}$ for the state of Ceará in the form of thematic maps on a monthly scale, using the Idrisi Andes (C) software, employing digital maps of longitude, latitude and altitude. For the altitude map, the digital elevation model (DEM) was used, obtained from the SRTM (Shuttle Radar Topography Mission) that resulted from the partnership between NASA (National Aeronautics and Space Administration) and NGA (National Geoespatial-Intelligence Agency), where the aim was to collect radar interferometry data with a view to acquiring detailed topographic models for latitudes between $56^{\circ} \mathrm{S}$ and $60^{\circ} \mathrm{N}$.

The whole process of MDE refinement also counted on the help of topographic control data, aimed at validation of the data generated. Radar data were collected during an 11-day mission, and subsequently processed according to the methodology described by Rabus et al. (2003). Despite the spatial resolution of the SRTM being $30 \mathrm{~m}$, the free SRTM images were resampled to a resolution of $90 \mathrm{~m}$, except for the US. SRTM data are referenced to the WGS84 ellipsoid. The SRTM data used in this work were acquired at http://Srtm.csi.cgiar:org. 
Solar radiation at the top of the atmosphere was determined using the methodology proposed by Allen et al. (1998) which considers the 15 th day of each month as reference in the calculation of the average $\mathrm{ET}_{\mathrm{o}}$ for each month.

To compare the results obtained by the Hargreaves and Samani equation (1985) and the temperature maps calculated by the digital terrain model, the ET was determined by the Hargreaves and Samani method (1985) for each location, based on climate data with the help of the REF-ET software (ALLEN, 2012). Estimates of ET by REF-ET software and those extracted from the generated maps were evaluated using simple error analysis (Equations 3 to 6).

$$
\begin{aligned}
& E M=\frac{\sum_{i=1}^{n}\left(y_{i}-x_{i}\right)}{n} \\
& E P E=\sqrt{\frac{\sum_{i=1}^{n}\left(y_{i}-x_{i}\right)^{2}}{n}} \\
& E P M=\frac{E M}{\bar{x}} \cdot 100 \\
& \xi=\frac{\bar{y}}{\bar{x}} .100
\end{aligned}
$$

where: ME is the mean error in $\mathrm{mm}^{\text {day }}{ }^{-1}$; SEE is the standard error of estimation in $\mathrm{mm}$ day $^{-1}$; MPE is the mean percentage error in $\%$; $\xi$ is the ratio between the means in $\%, \mathrm{n}$ is the number of data; $\mathrm{y}_{\mathrm{i}}$ is the EToHSMaps estimated by Hargreaves and Samani (1985) for maps; $\mathrm{x}_{\mathrm{i}}$ is the $\mathrm{ET}_{\text {oHSREF-ET }}$ estimated by Hargreaves using REF-ET; $\bar{x}$ and $\bar{y}$ are the averages of $\mathrm{ET}_{\text {oHsMaps }}$ and $\mathrm{ET}_{\text {oHSREF-ET }}$ for a given location respectively.

\section{RESULTS AND DISCUSSION}

The adjusted coefficients of determination of the regression equations for estimating mean monthly values for the minimum air temperature ranged from 0.98 in December to 0.92 in July; for the mean monthly values for the average air temperature they ranged from 0.98 in September and October, to 0.88 in February; for the mean monthly values for the maximum air temperature they were between 0.98 and 0.93 in April and October respectively (Table 2). It is worth noting that all the regression equations were significant at $5 \%$ significance by the F-test.

It was found that the $\mathrm{R}^{2}$ values obtained for the minimum as well as for the average and maximum temperatures were similar. This is probably due to the low variability of temperature data in the months in which they occurred. It was also observed that the maximum monthly value for the coefficient of determination was equal to 0.98 , not only for the minimum air temperature, but also for the maximum and average.

The values for $\mathrm{R}^{2}$ for the equations to estimate the minimum air temperature showed lower values since, of the twelve adjusted equations, six had values of less than 0.95 , the same happening with three of the equations for estimating the average air temperature and with one for estimating the maximum. With the equations for estimating the average air temperature it can be seen that the lowest value for the coefficient of determination $\left(\mathrm{R}^{2}=0.88\right)$ was obtained for the month of February, indicating lower precision of the estimates.

Pezzopane et al. (2004) studying the spatial distribution of air temperature in the state of Espírito Santo, obtained values for the adjusted coefficients of determination ranging from 0.88 to 0.94 for the minimum temperature, 0.89 to 0.92 for the average, and 0.94 to 0.98 for the maximum temperature. According to these authors, the fact of the coefficients of determination for the maximum temperature being higher than for the others, may be related to the greater uniformity of this climatic variable in the State.

The interval between February and July (Figure 2) presented the lowest demand for evapotranspiration in view of the absolute frequency distribution being offset to the left (lower values); almost all of the annual rainfall and the coldest months in the state being concentrated in this period.

Also according to Figure 2, we observe that from August until January the relative frequency values are shifted to the right, i.e. higher values of ET. October was the month with the highest demand for evapotranspiration in view of the fact that $57.7 \%$ of the values are around $5.55 \mathrm{~mm} \mathrm{day}^{-1}$. Tabari et al. (2012) in different regions of Iran noted the month of highest demand with a monthly $\mathrm{ET}_{\mathrm{o}}$ value of $534.4 \mathrm{~mm} \mathrm{month}^{-1}$ was July, while the lowest value was $25.6 \mathrm{~mm} \mathrm{month}^{-1}$ in January.

The inclusion of the digital elevation model in the spatialisation of Tx, Tn and Tmed using GIS, resulted in maps with greater detail and which represent the behavior of this variable as observed in the field and for different states in Brazil (BARDIN, PEDRO JÚNIOR; MORAES, 2010; MEDEIROS et al., 2005; PEZZOPANE et al., 2004). The maps of the estimates of maximum (Figure 3A), minimum (Figure 3B) and average temperatures (Figure 3C), for the month with the greatest demand for evapotranspiration, which according to Figure 2 was October, showed great geometric detail in accordance with the original detail of the digital elevation model, indicating that in studies that require more spatial details for temperature, it is necessary 
Table 2 - Regression coefficients of the equations for estimating the monthly values for average, maximum and minimum air temperatures with their respective coefficients of determination $\left(\mathrm{R}^{2}\right)$

Average temperature

\begin{tabular}{|c|c|c|c|c|c|c|c|c|c|c|c|}
\hline Month & A0 & $\mathrm{A} 1$ & A2 & A3 & A4 & A5 & A6 & A7 & A8 & A9 & $\mathrm{R}^{2}$ \\
\hline Jan & 70.39 & 0.07 & $-6.6 \mathrm{E}-06$ & 1.56 & 0.01 & 6.75 & -0.35 & $-1.5 \mathrm{E}-03$ & $1.9 \mathrm{E}-03$ & 0.26 & 0.96 \\
\hline Feb & -243.97 & 0.12 & $-7.8 \mathrm{E}-06$ & -14.33 & -0.19 & 8.75 & -0.23 & $-9.1 \mathrm{E}-04$ & $3.1 \mathrm{E}-03$ & 0.28 & 0.88 \\
\hline Mar & 196.60 & 0.04 & $-4.2 \mathrm{E}-06$ & 7.86 & 0.09 & 6.90 & -0.06 & $-6.7 \mathrm{E}-04$ & $1.3 \mathrm{E}-03$ & 0.19 & 0.93 \\
\hline Apr & 111.99 & -0.05 & 2.6E-06 & 4.89 & 0.07 & -4.53 & 0.16 & $-1.0 \mathrm{E}-06$ & $-1.0 \mathrm{E}-03$ & -0.16 & 0.95 \\
\hline May & 421.54 & -0.03 & $-2.4 \mathrm{E}-06$ & 19.72 & 0.25 & 3.35 & -0.03 & $-7.0 \mathrm{E}-04$ & $-4.8 \mathrm{E}-04$ & 0.08 & 0.95 \\
\hline Jun & 308.96 & 0.01 & $-5.2 \mathrm{E}-06$ & 12.04 & 0.12 & 16.28 & -0.06 & $-7.2 \mathrm{E}-04$ & $4.9 \mathrm{E}-04$ & 0.42 & 0.97 \\
\hline Jul & 20.47 & 0.05 & $-2.6 \mathrm{E}-06$ & -0.59 & -0.01 & 5.24 & -0.09 & $1.8 \mathrm{E}-04$ & $1.4 \mathrm{E}-03$ & 0.16 & 0.97 \\
\hline Aug & -34.28 & 0.05 & $-7.2 \mathrm{E}-06$ & -3.22 & -0.05 & 5.65 & -0.27 & $-1.5 \mathrm{E}-03$ & $1.4 \mathrm{E}-03$ & 21 & 0.95 \\
\hline Sep & 229.05 & 0.03 & $-4.4 \mathrm{E}-06$ & 9.70 & 0.11 & 8.07 & -0.24 & $-4.4 \mathrm{E}-04$ & 9.7E-04 & 0.28 & 0.98 \\
\hline Oct & -167.46 & -0.05 & 4.0E-08 & -9.62 & -0.12 & -0.99 & 0.01 & $-2.8 \mathrm{E}-05$ & $-1.1 \mathrm{E}-03$ & -0.01 & 0.98 \\
\hline Nov & 544.17 & -0.01 & $-1.2 \mathrm{E}-07$ & 27.33 & 0.35 & -2.36 & -0.33 & $-1.0 \mathrm{E}-03$ & $1.3 \mathrm{E}-04$ & 0.04 & 0.97 \\
\hline Dec & 170.92 & 0.01 & $1.8 \mathrm{E}-06$ & 8.75 & 0.12 & -6.00 & -0.20 & $-3.8 \mathrm{E}-04$ & 4.2E-04 & -0.08 & 0.94 \\
\hline \multicolumn{12}{|c|}{ Maximum temperature } \\
\hline Jan & 21.59 & -0.09 & $5.2 \mathrm{E}-07$ & 3.77 & 0.10 & -31.57 & -0.17 & $-1.6 \mathrm{E}-05$ & $-2.0 \mathrm{E}-03$ & -0.73 & 0.96 \\
\hline Feb & 155.71 & -0.10 & 3.6E-06 & 10.27 & 0.18 & -28.53 & -0.12 & $5.1 \mathrm{E}-04$ & $-2.2 \mathrm{E}-03$ & -0.67 & 0.97 \\
\hline Mar & 121.73 & -0.01 & $-1.3 \mathrm{E}-06$ & 6.60 & 0.10 & -13.09 & -0.23 & $1.6 \mathrm{E}-04$ & $-5.0 \mathrm{E}-05$ & -0.25 & 0.95 \\
\hline Apr & 200.89 & -0.10 & $3.6 \mathrm{E}-06$ & 11.37 & 0.18 & -19.52 & -0.01 & $3.8 \mathrm{E}-04$ & $-2.3 \mathrm{E}-03$ & -0.47 & 0.98 \\
\hline May & 673.78 & -0.15 & $3.9 \mathrm{E}-06$ & 34.90 & 0.47 & -17.30 & 0.06 & $2.6 \mathrm{E}-04$ & $-3.5 \mathrm{E}-03$ & -0.44 & 0.95 \\
\hline Jun & 899.34 & -0.12 & $1.2 \mathrm{E}-06$ & 46.59 & 0.62 & -15.93 & -0.19 & $-6.6 \mathrm{E}-04$ & $-2.8 \mathrm{E}-03$ & -0.35 & 0.96 \\
\hline Jul & 643.19 & -0.12 & $1.5 \mathrm{E}-06$ & 34.49 & 0.48 & -21.31 & -0.13 & $-3.9 \mathrm{E}-04$ & $-2.8 \mathrm{E}-03$ & -0.50 & 0.97 \\
\hline Aug & 162.08 & -0.07 & $5.5 \mathrm{E}-06$ & 12.32 & 0.22 & -35.30 & -0.42 & $9.6 \mathrm{E}-04$ & $-1.6 \mathrm{E}-03$ & -0.75 & 0.97 \\
\hline Sep & 223.72 & -0.09 & $8.8 \mathrm{E}-06$ & 16.15 & 0.28 & -39.01 & -0.17 & $2.3 \mathrm{E}-03$ & $-2.1 \mathrm{E}-03$ & -0.89 & 0.96 \\
\hline Oct & 122.48 & -0.12 & $6.6 \mathrm{E}-06$ & 10.24 & 0.20 & -37.60 & -0.11 & $1.0 \mathrm{E}-03$ & $-2.9 \mathrm{E}-03$ & -0.89 & 0.93 \\
\hline Nov & 137.00 & -0.07 & $5.0 \mathrm{E}-06$ & 10.83 & 0.20 & -34.41 & -0.18 & $7.2 \mathrm{E}-04$ & $-1.5 \mathrm{E}-03$ & -0.78 & 0.96 \\
\hline Dec & -91.71 & -0.05 & $2.6 \mathrm{E}-06$ & -1.78 & 0.02 & -29.77 & -0.39 & $5.0 \mathrm{E}-04$ & $-1.0 \mathrm{E}-03$ & -0.61 & 0.97 \\
\hline \multicolumn{12}{|c|}{ Minimum temperature } \\
\hline Jan & -28.50 & -0.04 & $-2.7 \mathrm{E}-06$ & -4.31 & -0.07 & 9.49 & 0.22 & $-7.8 \mathrm{E}-04$ & $-7.0 \mathrm{E}-04$ & & 0.95 \\
\hline Feb & -13.21 & 0.03 & $-3.9 \mathrm{E}-06$ & -3.65 & -0.07 & 12.21 & -0.20 & $-1.0 \mathrm{E}-03$ & $8.5 \mathrm{E}-04$ & 0.36 & 0.94 \\
\hline Mar & 91.89 & -0.07 & $-6.0 \mathrm{E}-06$ & 1.34 & -0.01 & 8.95 & 0.10 & $-1.2 \mathrm{E}-03$ & $-1.7 \mathrm{E}-03$ & 0.18 & 0.94 \\
\hline Apr & -3.25 & -0.02 & $-3.2 \mathrm{E}-06$ & -2.96 & -0.06 & 8.67 & 0.14 & $-3.8 \mathrm{E}-04$ & $-2.7 \mathrm{E}-04$ & 0.18 & 0.95 \\
\hline May & -30.56 & 0.01 & $-3.4 \mathrm{E}-06$ & -4.73 & -0.08 & 10.93 & 0.26 & $1.9 \mathrm{E}-04$ & $2.2 \mathrm{E}-04$ & 0.21 & 0.95 \\
\hline Jun & -164.60 & -0.01 & $1.3 \mathrm{E}-07$ & -11.43 & -0.17 & 11.42 & 0.12 & $5.5 \mathrm{E}-04$ & $-2.2 \mathrm{E}-04$ & 0.25 & 0.93 \\
\hline Jul & -7.52 & 0.01 & $-9.2 \mathrm{E}-06$ & -4.79 & -0.10 & 21.13 & -0.11 & $-1.7 \mathrm{E}-03$ & $3.2 \mathrm{E}-04$ & 0.54 & 0.92 \\
\hline Aug & -201.48 & 0.03 & $-4.8 \mathrm{E}-06$ & -13.79 & -0.21 & 17.19 & -0.18 & $-1.3 \mathrm{E}-03$ & $9.1 \mathrm{E}-04$ & 0.47 & 0.94 \\
\hline Sep & 50.94 & 0.09 & $-1.0 \mathrm{E}-05$ & -1.05 & -0.05 & 20.46 & -0.50 & $-1.6 \mathrm{E}-03$ & $2.4 \mathrm{E}-03$ & 0.64 & 0.97 \\
\hline Oct & 26.58 & 0.05 & $-8.4 \mathrm{E}-06$ & -3.69 & -0.10 & 29.08 & -0.03 & $-1.3 \mathrm{E}-03$ & $1.4 \mathrm{E}-03$ & 0.73 & 0.97 \\
\hline Nov & -173.68 & -0.04 & $-6.8 \mathrm{E}-06$ & -12.74 & -0.19 & 17.32 & 0.15 & $-1.1 \mathrm{E}-03$ & $-9.2 \mathrm{E}-04$ & 0.39 & 0.94 \\
\hline Dec & -23.08 & -0.03 & $-7.4 \mathrm{E}-06$ & -4.26 & -0.08 & 11.86 & -0.06 & $-1.4 \mathrm{E}-03$ & $-6.3 \mathrm{E}-04$ & 0.30 & 0.98 \\
\hline
\end{tabular}


Figura 2 - Frequency histograms for $\mathrm{ET}_{\mathrm{o}}$
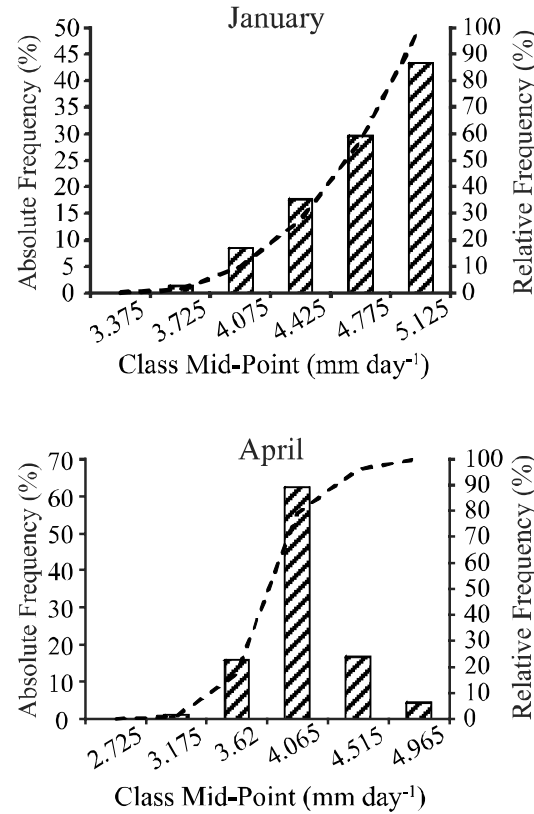

Class Mid-Point (mm day-1)

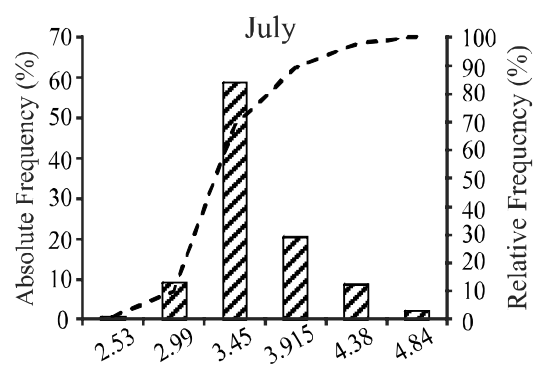

Class Mid-Point (mm day $\left.{ }^{-1}\right)$

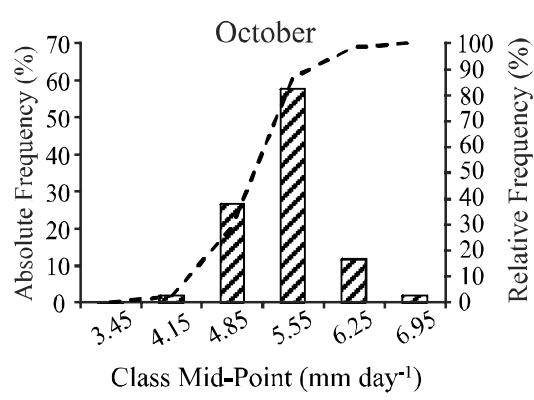

Class Mid-Point $\left(\mathrm{mm} \mathrm{day}^{-1}\right)$
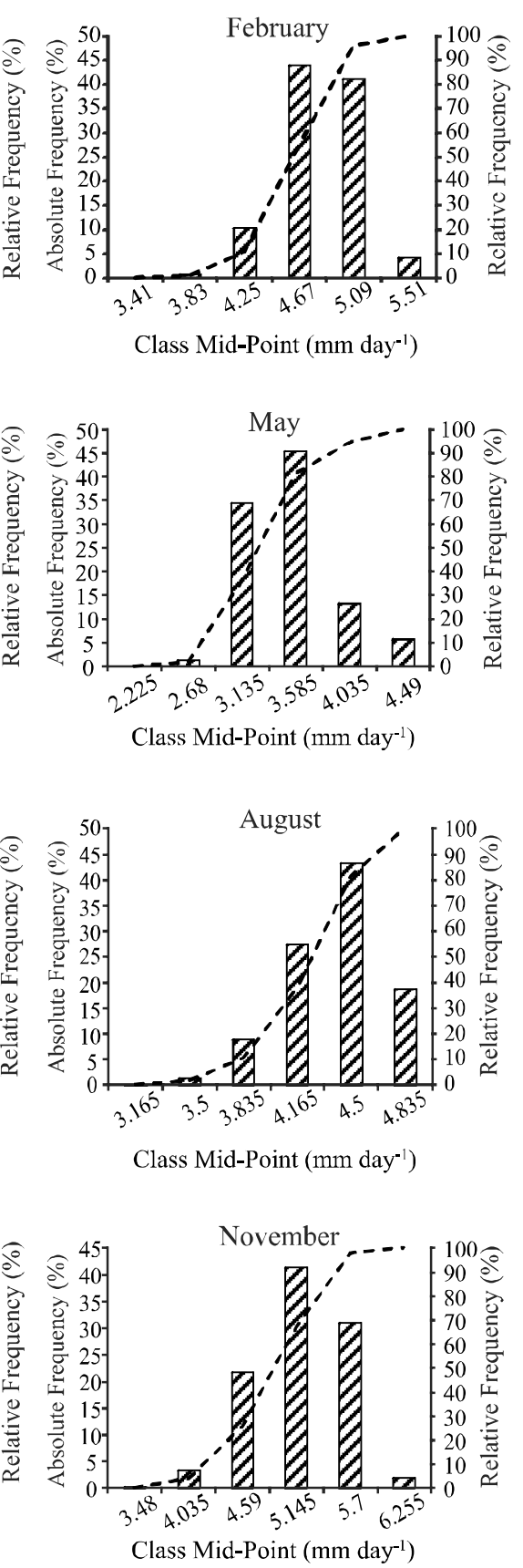
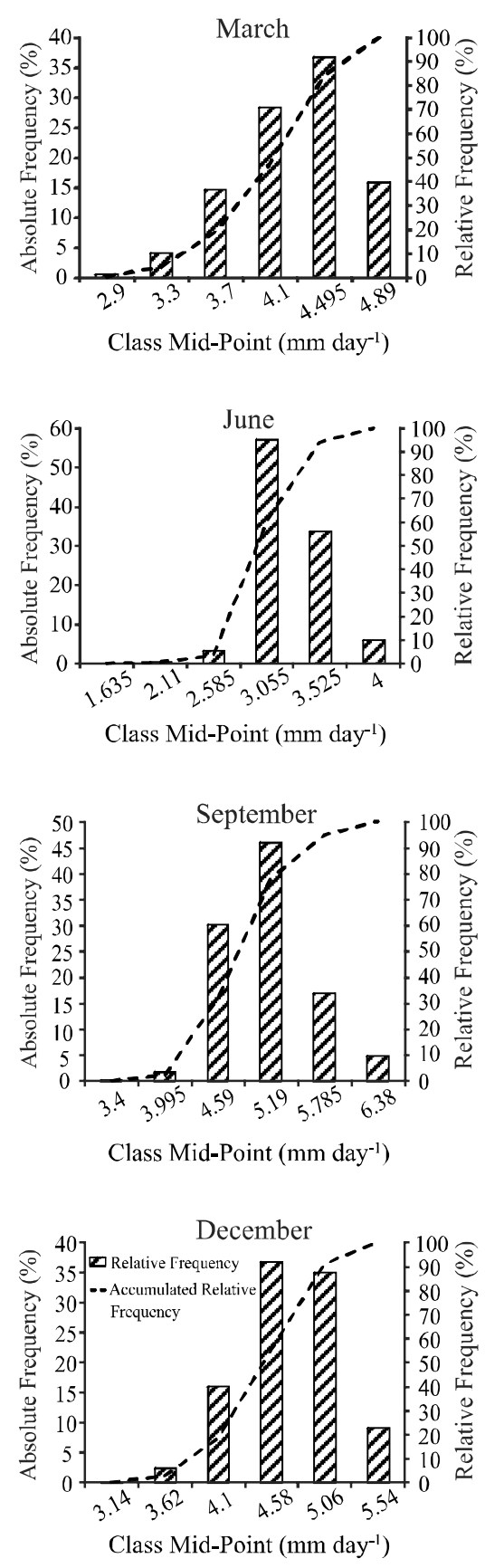

to run the equations on similarly detailed topographic maps Combining maps of the spatial distribution of ET with the spatial distribution of the meteorological variables will provide an important basis for the study of hydrological and climate modelling (AHMAD et al., 2005; FOOLADMAND; HAGHIGHAT, 2007; KONGO et al., 2011).

The thematic map of maximum air temperature (Figure 3A) showed values varying from $25^{\circ} \mathrm{C}$ to $38^{\circ} \mathrm{C}$. It was also found that for almost all regions of the state of
Ceará, the values seen were over $30^{\circ} \mathrm{C}$, with the exception of an area located in the Serra de Guaramiranga, which cuts across the towns of Redenção, Pacoti, Guaramiranga, Baturité and Aratuba, where the values for the maximum temperature were between $25^{\circ} \mathrm{C}$ and $27^{\circ} \mathrm{C}$, these values being associated with the higher altitudes in that area. The estimates of minimum temperature ranged between $10.1{ }^{\circ} \mathrm{C}$ and $24.3{ }^{\circ} \mathrm{C}$ for the month of October (Figure $3 \mathrm{~B})$. It's possible to see that low temperatures occurred 
in the regions of mountains and plateaus that cross the states of Ceará and Piauí, such as Serra Grande, the Chapada do Araripe and Serra Dois Irmãos. However, the average temperature varied between $18^{\circ} \mathrm{C}$ to $28^{\circ} \mathrm{C}$, with $50.7 \%$ of the area of the state having a temperature of $26.1^{\circ} \mathrm{C}$ (Figure $3 \mathrm{C}$ ).

Figure 3 - Maps of temperature and reference evapotranspiration in the month of maximum demand, for the state of Ceará: (A) maximum temperature; (B) minimum temperature; (C) mean temperature; (D) $\mathrm{ET}_{0}$; (E) temperature range
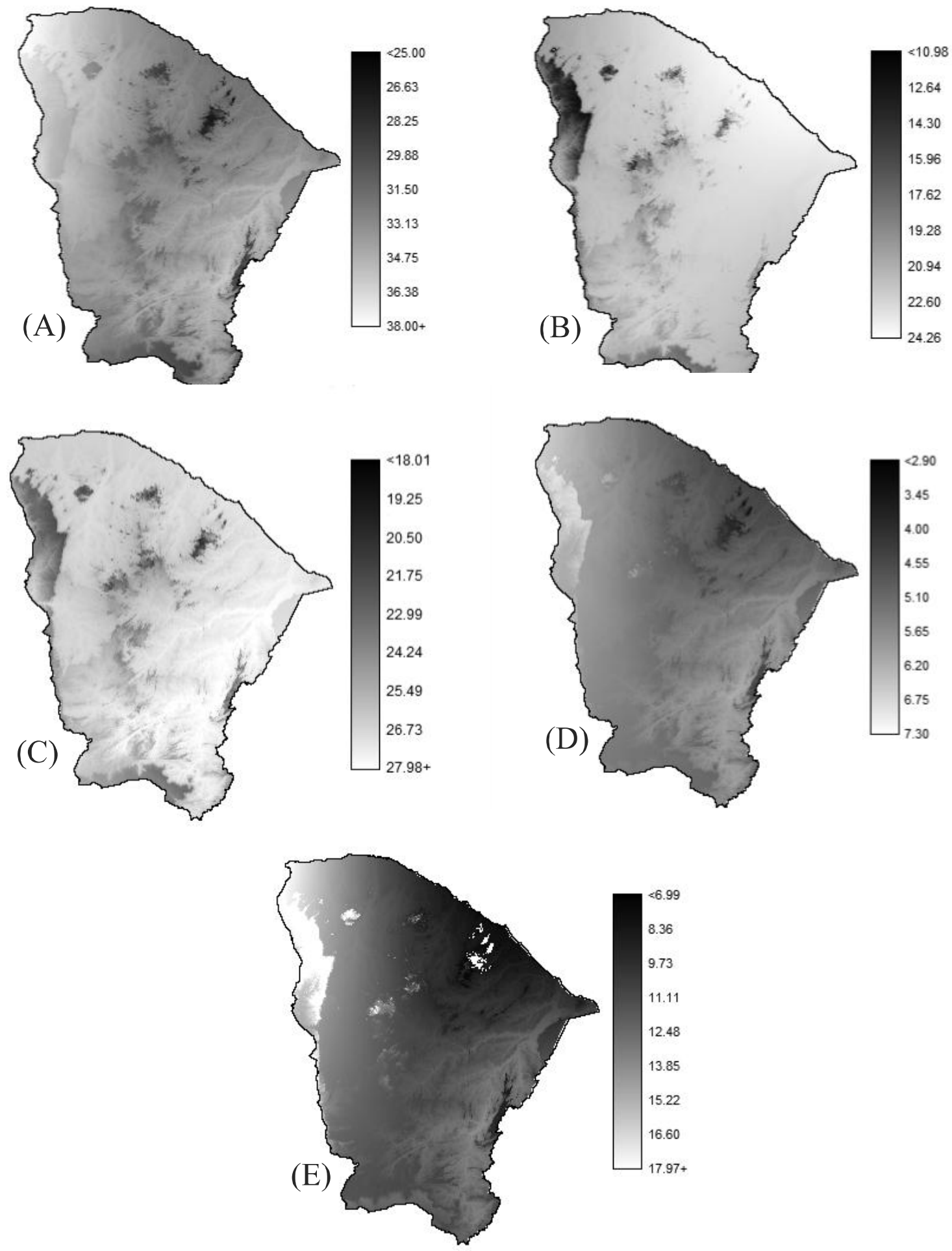
The spatial modeling of ET gives an understanding of the spatial and temporal variability of the demand for water in different regions of the state (Figure 3D). Xu et al. (2006) state that spatial distribution maps provide valuable information for the planning and management of water resources in a basin or region, since the spatial distribution of the seasonal and annual values for $\mathrm{ET}_{\mathrm{o}}$ is an important component of the hydrological cycle. From Figure 3D it can clearly be seen that the areas with a lower value for ET in the peak month are in the region of Serra de Guaramiranga, while the smallest values of ET were observed in the region of the Chapada da Ibiapaba (Serra Grande), going against the more obvious result, where the highest values of $\mathrm{ET}_{\mathrm{o}}$ should be in the driest part of the state, which lies in the central region. Two hypotheses can be raised to explain this result. The first can be attributed to the lack of weather stations in the region of Serra Grande when calibrating the regression equations for the temperatures, the region therefore being dependent on the neighboring stations of Sobral and Crateús in Ceará, and Parnaíba, Piripiri and Picos in Piauí (Figure 2). The second might be associated with the actual Hargreaves and Samani equation (1985) and its sensitivity to temperature variation, considering that the Serra Grande presented the highest values for thermal range (Figure 3E).

Figure 4 - Trend analysis of $\mathrm{ET}_{\mathrm{o}}$ obtained from the map and observed at the stations
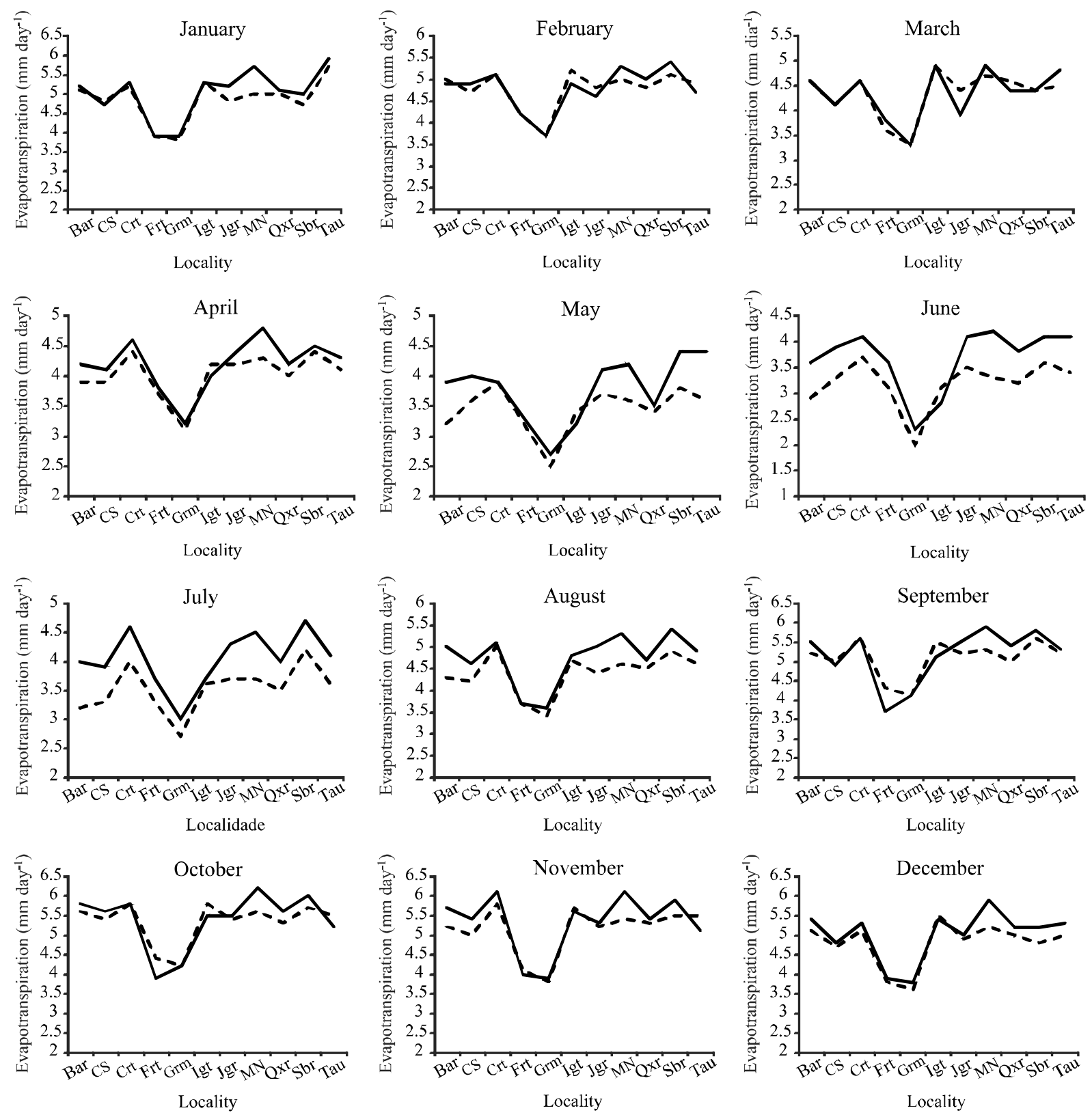
Figure 4 shows the comparison between the ET obtained from the temperature maps for the pixel containing a station, and the values obtained from the climatic data at that station. Comparison of the results between the methods tested, clearly shows variability from one location to another. It can be seen that for the stations of Morada Nova, Quixeramobim and Sobral the values obtained by the proposed method were always lower than those obtained by REF-ET, except in March. While the stations in Fortaleza and Iguatu presented the best results throughout the year, with closer values between methodologies.

It is worth noting that the Hargreaves and Samani equation (1985) tends to overestimate ET in humid regions and underestimate it in very dry regions and in those regions with higher wind speeds (TEMESGEN; ALLEN; JENSEN, 1999; XU; SINGH, 2002). Therefore, the Hargreaves and Samani equation (1985) requires local calibration before being applied to estimate $\mathrm{ET}_{\mathrm{o}}$ in any particular region (BAUTISTA, BAUTISTA, 2009; GAVILAN et al., 2006; FOOLADMAND; HAGHIGHAT, 2007).

Analyzing the values of $\xi$, It can be seen that in four months only, the values of $\mathrm{ET}_{\mathrm{o}}$ were underestimated when obtained from the temperature map in relation to the ET obtained by REF-ET (Table 3). The proposed methodology for estimating ET by the Hargreaves and Samani equation (1985) from altitude data produced satisfactory estimates, considering that seven months showed values that had been under or overestimated by less than $5 \%(\xi)$.

Table 3 - Ratio of the mean ( $\xi$ ), mean error (ME), standard error of estimation (SEE) and mean percentage error (MPE) between $\mathrm{ET}_{\mathrm{o}}$ estimated with the digital elevation model $\left(\mathrm{ET}_{\text {oHSMaps }}\right)$, and the REF-ET software $\left(\mathrm{ET}_{\text {oHSREF-ET }}\right)$ as estimated by Hargreaves and Samani (1985)

\begin{tabular}{lrrrr}
\hline \multirow{2}{*}{ Month } & \multicolumn{4}{c}{ Statistical índices } \\
\cline { 2 - 5 } January & \multicolumn{1}{c}{$\xi$} & ME & SEE & MPE \\
February & 99.80 & -0.17 & 0.29 & 3.62 \\
March & 100.20 & -0.02 & 0.21 & 3.28 \\
April & 96.00 & -0.17 & 0.25 & 4.88 \\
May & 91.70 & -0.34 & 0.48 & 9.40 \\
June & 87.10 & -0.50 & 0.61 & 14.85 \\
July & 87.40 & -0.52 & 0.58 & 12.64 \\
August & 93.00 & -0.35 & 0.44 & 7.01 \\
September & 99.30 & -0.07 & 0.36 & 5.45 \\
October & 99.60 & -0.05 & 0.33 & 4.81 \\
November & 96.90 & -0.18 & 0.37 & 5.25 \\
December & 95.60 & -0.23 & 0.31 & 4.74 \\
\hline
\end{tabular}

Taking into consideration only the average of all the locations for each month, the values of ME ranged from 0.0 to $-0.52 \mathrm{~mm} \mathrm{~d}^{-1}$, with a mean of $-0.22 \mathrm{~mm} \mathrm{~d}^{-1}$ (Table 3). SEE values ranged from 0.21 to $0.61 \mathrm{~mm} \mathrm{~d}^{-1}$ with a mean value of $0.31 \mathrm{~mm} \mathrm{~d}^{-1}$. Ratios between the mean values $(\xi)$ obtained with the two methods, showed that the greatest underestimation observed was $12.9 \%$ (June). Considering only the months of June and July, when the ET values obtained from the map showed the greatest underestimates, the values obtained for the mean percentage error (MPE) were 14.85 and $12.64 \%$ for the months of June and July respectively.

\section{CONCLUSIONS}

1. The proposed methodology did not show good results in the coldest months of the year (June and July) in the state of Ceará;

2. The methodology proposed for spatialising $\mathrm{ET}_{\mathrm{o}}$ by means of the Hargreaves and Samani equation (1985) using temperature maps obtained by the SRTM digital elevation model, proved to be a viable alternative in view of the results of the statistical analysis when compared to the standard method.

\section{REFERENCES}

AHMAD et al. A new technique to estimate net groundwater use across large irrigated areas by combining remote sensing and water balance approaches, Rechna Doab, Pakistan. Hydrogeology Journal, v. 13, n. 5/6, p. 653-664, 2005.

ALLEN, R. G. A Penman for all seasons. Journal Irrigation Drainage Engineering, v. 112, n. 4, p. 348-368, 1986.

ALLEN, R. G. et al. Crop evapotranspiration: guidelines for computing crop water requirements. Rome: FAO, 1998. (FAO Irrigation and Drainage Paper, 56).

ALLEN, R. G. REF-ET: Reference Evapotranspiration Calculation Software for FAO and ASCE Standardized Equations. University of Idaho, 2012.

BARBOSA, F. C.; TEIXEIRA, A. dos S.; GONDIM, R. S. Espacialização da evapotranspiração de referência e precipitação efetiva para estimativa das necessidades de irrigação na região do Baixo Jaguaribe - CE. Revista Ciência Agronômica, v. 36, n. 1, p. 24-33, 2005.

BARDIN, L.; PEDRO JÚNIOR, M. J.; MORAIS, J. F. L. Estimativa das Temperaturas máximas e mínimas do ar para a região do Circuito das Frutas, SP. Revista Brasileira de Engenharia Agrícola e Ambiental, v. 14, n. 6, p. 618-624, 2010 . 
BAUTISTA, F.; BAUTISTA, D. Calibration of the equations of Hargreaves and Thornthwaite to estimate the potential evapotranspiration in semi-arid and subhumid tropical climates for regional applications. Atmósfera, v. 22, n. 4, p. 331-348, 2009.

CARGNELUTTIFILHO, A.; MALUF, J. R. T.; MATZENAUER, R. Coordenadas geográficas na estimativa das temperaturas máximas e médias decendiais do ar no Estado do Rio Grande do Sul. Ciência Rural, v. 38, n. 9, p. 2448-2456, 2008.

DROOGERS, P.;ALLEN, R. G. Estimating reference evapotranspiration under inaccurate data conditions. Irrigation Drainage System, v. 16, n. 1, p. 33-45, 2002.

FOOLADMAND, H. R.; HAGHIGHAT, M. Spatial and temporal calibration of Hargreaves equation for calculating monthly $\mathrm{ET}_{\mathrm{O}}$ based on Penman-Monteith method. Irrigation and Drainage, v. 56, n. 4, p. 439-449, 2007.

GAVILÁN, P. et al. Regional calibration of Hargreaves equation for estimating reference ET in a semiarid environment. Agricultural Water Management, v. 81, n. 3, p. 257-281, 2006.

GAVILÁN, P.; BERENGENA, J.; ALLEN, R. G. Measuring versus estimating net radiation and soil heat flux: impact on Penman-Monteith reference ET estimates in semiarid regions. Agricultural Water Management, v. 89, n. 3, p. 275-286, 2007.

HARGREAVES, G. H.; SAMANI, Z. A. Reference crop evapotranspiration from temperature. Applied Engineered Agricultural, v. 1, n. 2, p. 96-99, 1985.

KONGO, M. V. et al. Evaporative water use of different land uses in the upper-Thukela river basin assessed from satellite imagery. Agricultural Water Management, v. 98, n. 11, p. 1727-1739, 2011.

LOPEZ-URREA, R. et al. An evaluation of two hourly reference evapotranspiration equations for semiarid conditions. Agricultural Water Management, v. 86, n. 3, p. 277-282, 2006.

MEDEIROS, S. de S. et al. Estimativa e espacialização das temperaturas do ar mínimas, médias e máximas na Região
Nordeste do Brasil. Revista Brasileira de Engenharia Agrícola e Ambiental, v. 9, n. 2, p. 247-255, 2005.

PEREIRA, A. R.; PRUITT, W. O. Adaptation of the Thornthwaite scheme for estimating daily reference evapotranspiration. Agricultural Water Management, v. 66, n. 3, p. 251-257, 2004.

PEZZOPANE, J. E. M. et al. Espacialização da temperatura do ar no Estado do Espírito Santo. Revista Brasileira de Agrometeorologia, v. 12, n. 1, p. 151-158, 2004.

RABUS, B. et al. The Shuttle Radar Topography Mission - a new class of digital elevation models acquired by spaceborne radar. ISPRS. Journal of Photogrammetry \& Remote Sensing, v. 57, n. 4, p. 241-262, 2003.

ROCHA, É. J. T. et al. Estimativa da Et ${ }_{\mathrm{o}}$ pelo modelo PenmanMonteith FAO com dados mínimos integrada a um Sistema de Informação Geográfica. Revista Ciência Agronômica, v. 42, n. 1, p. 75-83, 2011.

TABARI, H. et al. Spatial distribution and temporal variation of reference evapotranspiration in arid and semi-arid regions of Iran. Hydrological Processes, v. 26, n. 4, p. 500-512, 2012.

TEMESGEN, B.; ALLEN, R. G.; JENSEN, D. T. Adjusting temperature parameters to reflect well-water conditions. Journal of Irrigation and Drainage Engineering, v. 125, n. 1, p. 26-33, 1999.

VENTURA, F. et al. An evaluation of common evapotranspiration equations. Irrigation Science, v. 18, n. 4, p. 163-170, 1999.

WALTER, I. A. et al. ASCE's standardized reference evapotranspiration equation. Proc. 4th National Irrigation Symp. American Society of Agricultural Engineers, p. 209-215. 2000.

XU C.Y.; SINGH, V. P. Cross comparison of empirical equations for calculating potential evapotranspiration with data from Switzerland. Water Research Management, v. 16, p. 197-219, 2002.

XU, C. et al. Analysis of spatial distribution and temporal trend of reference evapotranspiration and pan evaporation in Changjiang (Yangtze River) catchment. Journal of Hydrology, v. 327, n. 1/2, p. 81-93, 2006. 